\title{
Innovation Competencies and Sustainability: A Proposed Model for Project Team Members
}

\author{
Afaf Hassan \\ Dept. of Environmental Health and Safety, Abu Dhabi University \\ PO Box 59911, Abu Dhabi, United Arab Emirates \\ E-mail: afaf.h-adjunct@adu.ac.ae
}

Received: July 1, 2021

Accepted: July 18, 2021

Published: July 20, 2021

doi:10.5296/ijrd.v8i2.18841

URL: http://dx.doi.org/10.5296/ijrd.v8i2.18841

\begin{abstract}
Acquiring the right innovation competencies can lead to a successful implementation of sustainability projects. Hence, the purpose of this study is to identify the innovation competencies required by project team members to adopt and implement innovation effectively in sustainability projects. To achieve this target, a comprehensive literature review has been performed to build a model that integrates innovation competencies of project team members with the successful achievement of substantiality projects. In specific, these innovation competencies are leadership, communication, teamwork, creativity, and commitment of project team members. The paper also reveals that a successful implementation of innovation in sustainability projects leads to economic growth, environmental protection, and social equity as main outcomes. Accordingly, this research proposes a model that presents the associations between project team members' innovation competencies and the implementation of sustainability projects (considering the three pillars of sustainability that are economic growth, environmental protection, and social equity). As a result, the project team members, who acquire the required innovation competencies, have the capability to implement sustainability projects, successfully.
\end{abstract}

Keywords: Innovation competences, sustainability, project team

\section{Introduction}

\subsection{Innovation Competencies and Sustainability Projects from Project Team Perspectives}

The adoption and implementation of innovation in projects is a challenging task (Cunha et al., 2014; Lahi \& Elenurm, 2015; Samson \& Gloet, 2014), specifically, if these projects are designed to attain sustainability (Hassan, 2021a; Secundo et al., 2020). Here, it is essential to point out that innovation challenges in projects come from clients' pressure to minimize costs, 
improve quality, and expedite the implementation processes (Dulaimi et al., 2005; Hassan, 2021a). Though, innovation may not be implemented successfully in projects because of many reasons such as failure to create appropriate conditions for a successful adoption, unprofessional selection of project members, or unsuitable project culture (Samson \& Gloet, 2014). This highlights the critical role of project team members in handling and controlling projects (Hills et. al, 2008), as only those who have robust innovation competencies can deliver innovation successfully in sustainable projects (Adiguzel \& Cakir, 2020; Brook \& Pagnanelli, 2014; Dumitrescu et al., 2014; Hassan, 2021a; Powl \& Skitmore, 2005). The reason is that once project team members are fully convinced about the advantages of innovations, it becomes easy for them to adopt and deliver innovation in sustainable projects, in a unique manner (Adiguzel \& Cakir, 2020; Brook \& Pagnanelli, 2014; Dulaimi et al., 2005; Hassan, 2021a).

\subsection{Rational of the Study}

Lahi and Elenurm (2015) have emphasized that the competencies of project teams can act as catalysts or barriers to innovation. The reason is that failure to deliver innovation in projects comes from many factors such as lack of innovation initiatives, inexperienced resources, or difficulty in dealing with technologies (Cunha, et al. 2014). At the same time, adopting and implementing innovation successfully requires creative and innovative project team members, specifically when dealing with sustainability projects (Dul \& Ceylan, 2014). Kempner-Moreira et al. (2020) have added that to achieve competitive outcomes in terms of innovation, there should be an effective project team that presents main competencies for innovation, mapping them and assuring that their abilities promote innovation successfully in sustainability projects. This is in line with the argument of other scholars, who have emphasized that innovation influences sustainability projects in a positive way, as it obtains a competitive advantage among internal and external stakeholders (Brook \& Pagnanelli, 2014; Desidério et al., 2020; Hassan, 2021a).

However, there is a lack of understanding about the project team members' innovation competencies that can enhance the delivery of innovation in sustainable projects (Adiguzel \& Cakir, 2020; Brook \& Pagnanelli, 2014; Dumitrescu et al., 2014; Hassan, 2021a; Vila et al., 2014). Ahsan et al. (2013) have emphasized that depending on the scope of work and type of sustainable project, the project team members' innovation competencies can vary in depth and breadth. This means that it is possible to differentiate between average and outstanding project team members through observing and recognizing their innovation competencies. This also implies that realizing the competencies and abilities of the different team members enhances the opportunity of achieving successful sustainability projects.

Many studies that deal with innovation competencies have involved knowledge about sustainability, yet they are not adequate, on their own, to ensure that project team members can deliver innovation successfully in sustainability projects (Hassan, 2021a; Skulmoski, \& Hartman, 2010). Besides, scholars have not reached an agreement about the effective innovation competencies, of project team members, which are essential to implement innovation in sustainability projects (Afsar et al., 2015; Adiguzel \& Cakir, 2020; Brook \& 
Pagnanelli, 2014; Hassan, 2021a; Liikamaa, 2015; Montani, Odoardi \& Battistelli, 2014; Vila et al., 2014). Accordingly, this research aims to fulfill this gap.

\section{Method}

This study demonstrates a conceptual model, using the revision of the existing literature about innovation competencies and the successful implementation of innovation in sustainability projects. In particular, this exploratory research is keen on evaluating the relationship between project team members' innovation competencies and the implementation of innovation, effectively, in sustainability projects. Thus, the literature was reviewed systematically in three main stages. First, the perceptions of innovation competencies and sustainability projects have been identified (Abu Bakar et al., 2011; Adiguzel \& Cakir, 2020; Brook \& Pagnanelli, 2014; Dzhengiz \& Niesten, 2019; Rojas, 2013; Vila et al., 2014). Second, the arguments supporting the existence of a relationship between project team members' innovation competencies (leadership, communication, creativity, teamwork, and commitment) and the implementation of sustainability projects have been explained (Adiguzel \& Cakir, 2020; Brook \& Pagnanelli, 2014; Dzhengiz \& Niesten, 2019; Guillén \& Saris 2013; Hassan, 2021a; Liikamaa, 2015; Mukhopadhyay et al., 2011). Third, a model illustrating the association between project team members' innovation competencies and the completion of sustainability projects (considering the three pillars of sustainability that are economic growth, social equity, and environmental protection) has been presented (Adiguzel \& Cakir, 2020; Brook \& Pagnanelli, 2014; Bruwer et al., 2018; Chung et al., 2016; Dzhengiz \& Niesten, 2019; Hassan, 2021a; Mukhopadhyay et al., 2011; Liikamaa, 2015; Remington-Doucette \& Musgrove, 2015; Secundo et al., 2020; Wiek et al., 2011). Generally, this study has assessed the subject based on available knowledge and information. It has also helped in recognizing the key innovation competencies, that project team members need to acquire, to deliver innovation effectively in sustainability projects (Afsar et al., 2015; Adiguzel \& Cakir, 2020; Brook \& Pagnanelli, 2014; Hassan, 2021a; Liikamaa, 2015; Montani et al., 2014; Vila et al., 2014). Hence, the researcher has thoroughly studied, analyzed, and integrated the content of forty-five high-quality articles that related to this study, and these had been selected carefully to fulfill the purpose of the research.

\section{Literature Review}

\subsection{Innovation Competencies}

Innovation is a new idea, design, material, method, process, or technology that individuals adopt in a project to gain additional benefits, in spite of any associated risks or uncertainties that might take place (Paladino, 2007; Samson \& Gloet, 2014). On the other side, Liikamaa (2015) has described competencies as individuals' essential characteristics, which are often linked to efficient outcomes in projects; competencies can predict behavior in several situations and work activities; project team members need competencies, which are abilities to apply knowledge efficiently and to make things happen; competencies disclose what team members are capable of doing and why they act in a certain manner (Liikamaa, 2015). Accordingly, in this study, innovation competencies are defined as the project team members' characteristics and behaviors that allow them to adopt and implement new ideas, methods, 
processes or technologies effectively in projects (Liikamaa, 2015; Paladino, 2007; Samson \& Gloet, 2014). However, the competencies of a project team members can vary in depth and breadth depending on a project's type and scope of work (Ahsan et al., 2013; Muller \& Turner, 2007).

In general, scholars have argued that there is a relationship between project team members' innovation competencies and the success of a project (Muller \& Turner, 2007). Crant (2000) has emphasized that creativity and proactivity (or pro-activeness) are the main innovation competencies. Aragón-Correa et al. (2007) have emphasized that leadership competency is the most critical innovation competency. The reason is that leadership has a substantial effect on project team members' learning, which indirectly influences the implementation of innovation in projects (Aragón-Correa et al., 2007). But it is imperative to emphasize that there is a positive relationship between leadership and project team members' innovation competencies, as leadership influences project teams' creativity through psychological inspiration (Gumusluoglu \& Ilsev, 2009). Problem-solving, collaboration, and knowledge about the market are considered to be the main innovation competencies that can lead team members to project success (Atuahene-Gima \& Wei, 2010). Then, Montani et al. (2014) have provided a different opinion, as they have stated that goal generation and proactive planning are the key innovation competencies. Vila et al. (2014) have suggested that the main innovation competencies for project team members are the alertness to new opportunities and the capability to present novel ideas, products, or reports. Later, Afsar et al. (2015) have mentioned that trust is an important innovation competency. The reason is that trust provides project team members with the opportunity to present more innovative ideas and become convinced about adopting and applying new ideas (Afsar et al., 2015). In other words, it is clear that scholars have different viewpoints about the key innovation competencies that enable project team members to achieve sustainability in projects (Afsar et al., 2015; Crant, 2000; Montani et al., 2014; Vila et al., 2014).

\subsection{Sustainability Projects}

Sustainability perceptions, measurements, changes, and priorities are still being studied (Ciegis et al., 2011). Commonly, sustainability deals with a wide range of economic, environmental, and social issues, including biodiversity, climate change, energy, gender, equality, healthcare, education, food supply, peace, security, economic growth, and sustainable production (Secundo et al., 2020). The main purpose of adopting sustainability projects is to offer effective solutions for complicated challenges such as pollution, ecosystem resilience, climate change, food security, energy, migration, and many other issues that demand a cross-disciplinary standpoint (Secundo et al., 2020). More specifically, sustainability projects intend to inspire current generations to meet their needs without compromising the capacity of future generations to meet their needs (Remington-Doucette \& Musgrove, 2015). Sustainability projects also provide responses to present and anticipated matters such as climate change, desertification, poverty, pandemics, a war that are, often, presenting high degrees of urgency, damage potential, and complexity (Wiek et al., 2011). Sustainability projects lead to the formation of agreements and partnerships between local governments and their communities. The support of local governance is imperative, 
specifically, for project team members working on sustainability projects. The reason is that these team members become key actors to attain more local development, they also feel responsible for the goals and visions of development established in local policies, regulations, and laws. The transformation towards sustainability projects requires more transparent decisions that can inspire a wide range of stakeholders to participate in achieving the sustainable development goals (Sobol, 2008). Besides, the project team members are responsible to resolve conflicts and any uncertainty associated with innovation, along with the establishment of positive outcomes for sustainability projects as a result of creating a fair working environment for all involved team members (Adiguzel \& Cakir, 2020). Nevertheless, the success of sustainability projects requires project team members to acquire robust innovation competencies, which allows them to overcome any challenges or obstacles that could be confronted in their way towards achieving sustainability (economic, environmental, and social) goals (Ciegis et al., 2011; Dumitrescu et al., 2014; Dzhengiz \& Niesten, 2019; Remington-Doucette \& Musgrove, 2015; Sobol, 2008).

\subsection{Innovation Competencies and Sustainability}

However, project team members' innovation competencies that are most frequently mentioned in the literature, to have an influence on the adoption and implementation of sustainability in projects are:

\subsubsection{Leadership Competencies}

There are several leadership competencies that enable project team members to implement innovation successfully in sustainability projects (Adiguzel \& Cakir, 2020; Boss, 2000; Brook \& Pagnanelli, 2014; Dumitrescu, et. al. 2014; Dzhengiz \& Niesten, 2019; Howell et al. 2005; Liikamaa, 2015). In justification, it is imperative for project team members to inspire each other's to create novel ideas and find new opportunities (Liikamaa, 2015;). Proactively take the initiative to innovate in sustainability projects (Adiguzel \& Cakir, 2020; Dzhengiz \& Niesten, 2019; Liikamaa, 2015). Use proper influence strategies to navigate around or get rid of any problem (Howell et al., 2005). Make a decision that helps in delivering innovation successfully in sustainability projects (Boss, 2000; Brook \& Pagnanelli, 2014). Avoid analysis paralysis when new chances are recognized through showing a preference towards action (Liikamaa, 2015). Be alerted to new chances and get adapted to challenges, easily (Liikamaa, 2015; Takey \& Carvalho, 2015). Care about building, strengthening, and developing new relationships (Liikamaa, 2015). Also, find creative and practical ways to resolve conflicts (Takey \& Carvalho, 2015). In other words, the project team members' leadership competencies that enhance the implementation of innovation in sustainability projects are inspiring others, initiative, influencing, decision making, action-Oriented, flexibility, relationship building, and conflict resolution (Adiguzel \& Cakir, 2020; Brook \& Pagnanelli, 2014; Dzhengiz \& Niesten, 2019; Guillén \& Saris 2013; Liikamaa, 2015; Mukhopadhyay et al., 2011).

\subsubsection{Communication}

There are numerous communication competencies that allow project team members to apply 
innovation effectively in sustainability projects (Abu Bakar et al., 2011; Dzhengiz \& Niesten, 2019; Hassan, 2021; Rojas, 2013; Vila et al., 2014). In support, it is crucial for project team members to carefully listen to each other without interruption (Rojas, 2013). Speak using clear language, which is suitable to the audience (Dumitrescu et al., 2014; Rojas, 2013; Vila et al., 2014). Write (emails, proposals, memos, letters, reports, etc.) clearly using a local or foreign language (Abu Bakar et al., 2011; Vila et al., 2014). Prepare presentations about products, ideas, or reports, and present them precisely (Vila et al., 2014). Also, communicate in a tone that demonstrates respect to other team members (Rojas, 2013). Accordingly, the project team members' communication competencies that enhance the implementation of innovation in sustainability projects are being able to (appropriately) listen, speak, write, present, and select the right tone (Abu Bakar et al., 2011; Adiguzel \& Cakir, 2020; Brook \& Pagnanelli, 2014; Dzhengiz \& Niesten, 2019; Rojas, 2013; Vila et al., 2014).

\subsubsection{Teamwork}

There are many teamwork competencies that allow project team members to realize innovation fruitfully in sustainability projects (Abu Bakar et al., 2011; Bossink, 2002; Hassan, 2021a; Liikamaa, 2015; Ríos-Carmenado et al., 2014; Takey \& Carvalho, 2015). In clarification, it is imperative for project team members to collaborate with each other's team to accomplish all assigned tasks or activities (Abu Bakar et al., 2011; Dumitrescu et al., 2014; Liikamaa, 2015; Ríos-Carmenado et al., 2014). Share knowledge, expertise, and responsibility to strengthen team performance (Bossink, 2002; Shieh, 2011). Solve problems vigorously whenever they occur (Takey \& Carvalho, 2015). Seek personal and team development through encouraging the creation and adoption of new ideas (Abu Bakar et al., 2011; Dainty, Liikamaa, 2015; Ríos-Carmenado et al., 2014; Takey \& Carvalho, 2015). In short, the project team members' teamwork competencies that enhance the employment of innovation in sustainability projects are collaboration, knowledge sharing, problem-solving, and personal and team development (Abu Bakar et al., 2011; Adiguzel \& Cakir, 2020; Bossink, 2002; Brook \& Pagnanelli, 2014; Dumitrescu et al., 2014; Dzhengiz \& Niesten, 2019; Liikamaa, 2015).

\subsubsection{Creativity}

There are various creativity competencies that allow project team members to implement innovation successfully in sustainability projects (Abu Bakar et al., 2011; Dumitrescu et al., 2014; Dziekoński, 2017; Hassan, 2021b; Howell, Shea \& Higgins 2005; Takey \& Carvalho, 2015). In explanation, it is fundamental for project team members to create new ideas through combining the existing ones (Dziekoński, 2017; Ríos-Carmenado, Rahoveanu \& Gallegos, 2014; Takey \& Carvalho, 2015). Evaluate products or services to see how they can be improved (Abu Bakar et al., 2011). Think about different ways to conduct various tasks and activities (Abu Bakar et al., 2011; Dziekoński, 2017). Look for new and surprising connections between things (Abu Bakar et al., 2011; Dziekoński, 2017; Hassan, 2021b; Takey \& Carvalho, 2015). Think outside the box to approach challenges (Dumitrescu et al., 2014; Hassan, 2021b; Howell et al., 2005). Consequently, the project team members' creativity competencies that improve the application of innovation in sustainability projects are 
combining ideas, improving work, finding different approaches, exploring new links, thinking outside the box (Abu Bakar et al., 2011; Adiguzel \& Cakir, 2020; Brook \& Pagnanelli, 2014; Dumitrescu et al., 2014; Hassan, 2021b; Dzhengiz \& Niesten, 2019; Dziekoński, 2017; Hossain, 2021; Maier et al., 2020).

\subsubsection{Commitment}

There are several commitment competencies that enable project team members to deliver innovation successfully in sustainability projects (Dzhengiz \& Niesten, 2019; Howell et al., 2005; Liikamaa, 2015; Ling, 2003; Rojas, 2013). In justification, it is important for project team members to put in excessive effort to adopt and apply innovative ideas (Rojas, 2013). Get fully engaged when conducting innovation-related activities (Ríos-Carmenado et al., 2014). Alter and change any course of action in order to get adapted as needed (Liikamaa, 2015). Believe that the main satisfaction in life comes from creating and realizing innovative ideas (Rojas, 2013). Trust that the most significant achievements that take place involve innovation (Howell et al., 2005). In brief, the project team members' commitment competencies that improve the application of innovation in sustainability projects are hard work, engagement, adaptability, satisfaction, and achievement (Brook \& Pagnanelli, 2014; Dzhengiz \& Niesten, 2019; Hassan, 2021; Howell et al., 2005; Liikamaa, 2015; Rojas, 2013).

\section{Proposed Model for Innovation Competencies and Sustainability Projects}

Innovation is essential to improve the quality of existing and new sustainability projects (Ciegis et al., 2011; Fukuda-Parr \& Muchhala, 2020; Mukhopadhyay et al., 2011; Remington-Doucette \& Musgrove, 2015; Secundo et al., 2020). Given that sustainability projects, in common, aim to integrate different strategies related to economic growth that, in turn, fosters environmental conservation and social inclusion (Fukuda-Parr \& Muchhala, 2020). This agrees with the nature of current projects, which are directed towards collaborating the three main pillars of sustainability that are economic growth, environmental protection, and social equity (Secundo et al., 2020; Sobol, 2008; Wiek et al., 2011). Though, sustainability projects require project team members, who acquire effective innovation competencies, to overcome suitability challenges in projects, and show the capability to complete all sustainability activities and tasks successfully (Bruwer et al., 2018; Dumitrescu, et al., 2014; Dzhengiz \& Niesten, 2019; Hassan, 2021a; Liikamaa, 2015; Mukhopadhyay et al., 2011; Wiek et al., 2011). Accordingly, this study has proposed a model that validates the existence of associations between project team members' innovation competencies and the achievement of sustainability projects as shown in Figure 1. This proposed model demonstrates project team members' innovation competencies that are most frequently mentioned in the literature to influence sustainability projects. These competencies will allow project team members to perform better and achieve outstanding outcomes in sustainability projects (Adiguzel \& Cakir, 2020; Brook \& Pagnanelli, 2014). In this regard, Vila et al. (2014) have mentioned that project teams can increase the probability of implementing innovation successfully in sustainability projects. This can be accomplished when all involved individuals understand their responsibilities towards innovation and become influencers to each other's (Dulaimi et al., 2005). Hence, this allows the project team members not only to 
develop innovative practices on the project site but also achieve the desired sustainability targets and objectives (Dulaimi et al., 2005; Secundo et al., 2020; Wiek et al., 2011).

In particular, the model illustrated in Figure 1 presents five key innovation competencies that should be acquired by project team members to complete sustainability projects, successfully. First, leadership competencies that involve inspiring others, taking initiative, influencing others, making decisions, being action-oriented, showing flexibility, building relationships, resolving conflicts (Abraham et al., 2001; Adiguzel \& Cakir, 2020; Boss, 2000; Brook \& Pagnanelli, 2014; Hassan, 2021a; Howell et al., 2005; Liikamaa, 2015). Adiguzel and Cakir (2020) have stated that leadership competencies positively affect innovation in sustainability projects. The reason is that individuals who acquire these competencies act socially and do their best to establish high teamwork performance (Adiguzel \& Cakir, 2020). In line with this argument, Brook and Pagnanelli (2014) have stated that the success of innovation in sustainability projects could be traced back to the loyalty and support of project team members who show leadership competencies throughout the period of a project (Brook \& Pagnanelli, 2014). This indicates that there is a relationship between leadership competencies and completing sustainability projects. Second, communication competencies that include critical skills, which are listening, speaking, writing, presenting, and selecting the right tone to communicate ideas and actions related to implementing innovation in sustainability projects (Abu Bakar et al., 2011; Adiguzel \& Cakir, 2020; Brook \& Pagnanelli, 2014; Hassan, 2021a; Rojas, 2013; Vila et al., 2014; Wei et al., 2013). Communication competencies are imperative, particularly when dealing with diverse team members (Adiguzel \& Cakir, 2020). The reason is that they help in decreasing conflict, reduce additional education expenses, and decrease communication problems (Adiguzel \& Cakir, 2020). Though, Brook and Pagnanelli (2014) have mentioned that teams should communicate innovation strategies on a tactical level to establish fruitful communication about the implementation of innovation in sustainability projects. This implies that there is an association between communication competencies and completing sustainability projects. Third, teamwork competencies that cover collaboration, knowledge sharing, problem-solving, and individuals' development, considering a common goal that is enhancing the overall outcome of a sustainability project (Abu Bakar et al., 2011; Adiguzel \& Cakir, 2020; Brook \& Pagnanelli, 2014; Dzhengiz \& Niesten, 2019; Guillén \& Saris 2013; Hassan, 2021; Liikamaa, 2015). The reason is that these teamwork competencies require team members to consider alternatives, propose new development processes, and create new marketing channels (Adiguzel \& Cakir, 2020). The teamwork competencies also encourage teams to collaborate with each other to assess methods, control complexities, improve quality, support sustainability activities, provide required maintenance, and collaborate to tape into internal or external knowledge that complements technology capabilities in sustainability projects (Brook \& Pagnanelli, 2014). This signifies that that teamwork competencies have a relationship with achieving sustainability projects. Fourth, creativity competencies that entail combining ideas, improving existing work processes, finding different approaches, exploring new links, and thinking outside the box to overcome all existing or expected challenges that might occur when implementing sustainability projects (Abu Bakar et al., 2011; Adiguzel \& Cakir, 2020; Brook \& Pagnanelli, 2014; Hossain, 2021; Maier et al., 2020). These competencies are crucial for 
the success of innovation in sustainability projects (Adiguzel \& Cakir, 2020; Brook \& Pagnanelli, 2014; Dzhengiz \& Niesten, 2019; Howell et al., 2005; Hossain, 2021; Maier et al., 2020). In clarification, the creative activities of a project team positively affect the success of innovation in sustainability projects (Adiguzel \& Cakir, 2020). In support, other scholars have argued that the world and global society, most probably, need to become more responsible with economic, environmental, and social issues, however, this cannot be achieved without utilizing creative ideas and innovations (Maier et al., 2020). It is also crucial to understand that creativity competencies make values in sustainability projects through adopting and applying innovation (Hossain, 2021). This can be done by blending advanced knowledge about innovation with local practices to utilize the innovative ideas successfully in sustainability projects (Hossain, 2021). This is performed by collecting data across functional units to evaluate the value made by innovation in sustainability projects (Hossain, 2021). Also, focusing on creating a broader market, evaluating the value creation based on innovation performance, and concentrating on knowledge and innovations that help to create value from sustainability in the short-term as well as long-term (Brook \& Pagnanelli, 2014). This can be achieved through presenting the best practices to balance the efforts made on sustainability projects through applying innovation effectively (Brook \& Pagnanelli, 2014). In turn, this will strengthen the competitiveness of sustainability projects in the short term, while generating opportunities to sustain competitiveness in the future (Brook \& Pagnanelli, 2014). This means that there is an association between creativity competencies and the implementation of sustainability projects. Last, commitment competencies that comprise of hard work, engagement, adaptability, satisfaction, and achievement among project team members, in order to achieve the goals of sustainability projects (Brook \& Pagnanelli, 2014; Dumitrescu et al., 2014; Liikamaa, 2015; Rojas, 2013). The success of innovation in many sustainability projects could be traced back to the commitment and support of the project team (Brook \& Pagnanelli, 2014). This indicates that commitment competencies are related to the completion of sustainability projects. Accordingly, the model shown in Figure 1 represents the innovation competencies, which project team members need to acquire, to complete sustainability projects successfully. 


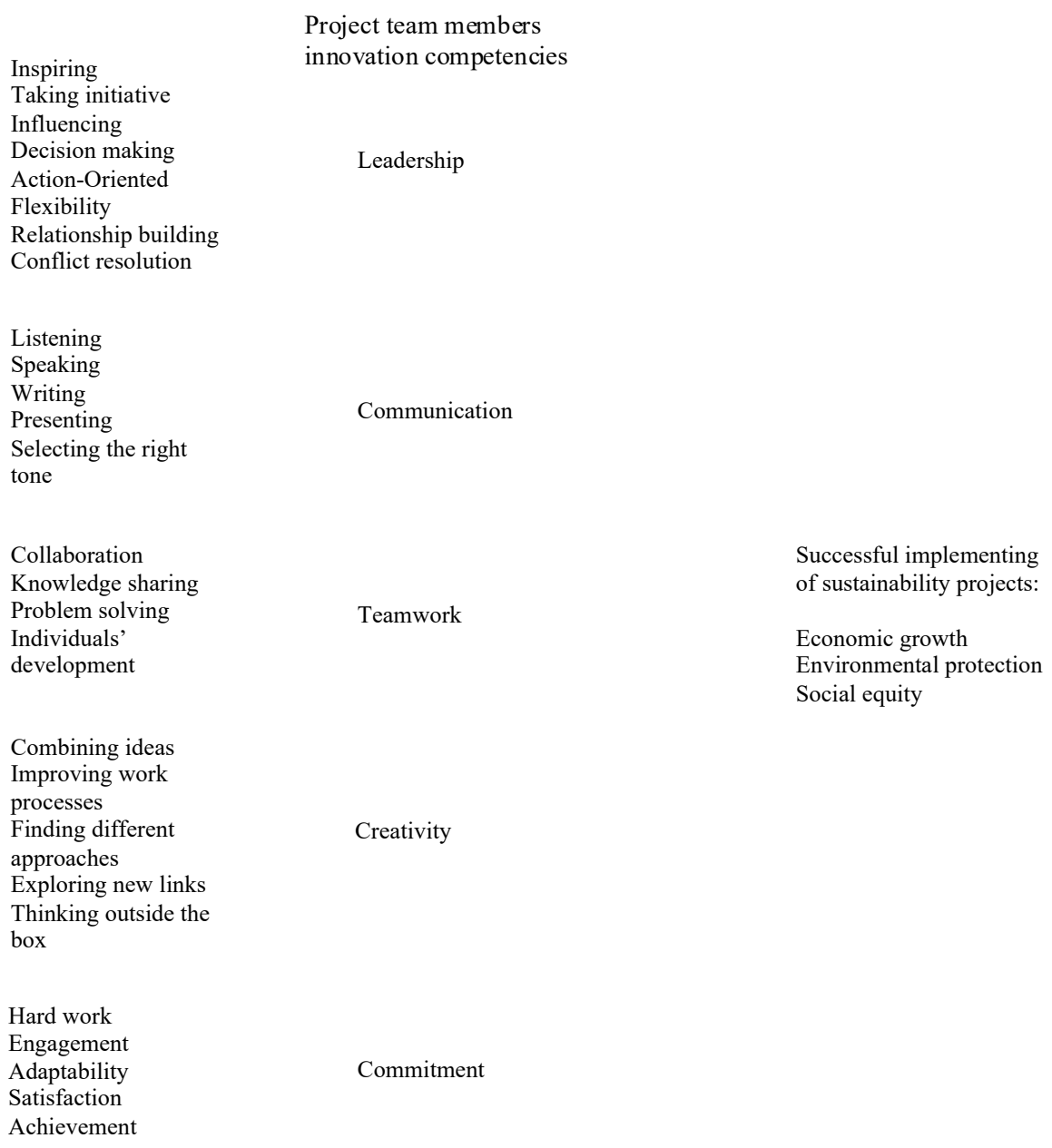

Figure 1. A model for project team members' innovation competencies and the successful implementation of sustainability projects

Source: Developed by the author

\section{Conclusion}

Project team members, who have the right innovation competencies, are capable of implementing sustainability projects effectively (Abu Bakar et al., 2011; Adiguzel \& Cakir, 2020; Brook \& Pagnanelli, 2014; Dumitrescu et al., 2014; Hassan, 2021a; Guillén \& Saris 2013; Liikamaa, 2015). These innovation competencies include leadership, communication, teamwork, creativity, and commitment to innovation in sustainability projects (Abu Bakar et al., 2011; Adiguzel \& Cakir, 2020; Brook \& Pagnanelli, 2014; Dainty et al., 2005; Dziekoński, 2017; Guillén \& Saris 2013; Liikamaa, 2015; Ríos-Carmenado et al., 2014; Takey \& Carvalho, 2015). Besides, the model initiated, in this study, illustrates the specific elements of each one of the adopted innovation competencies. In turn, it is imperative to point out that the appropriate adoption and implementation of innovation in sustainability projects will result in economic growth, environmental protection, and social equity (Bruwer et al., 2018; Chung et 
al., 2016; Dzhengiz \& Niesten, 2019; Mukhopadhyay et al., 2011; Remington-Doucette \& Musgrove, 2015; Wiek et al., 2011). In other words, the proposed model illustrates the existence of associations between the project team members' innovation competencies and the successful implementation of sustainability projects. More specifically, there is a relationship between innovation competencies (leadership competencies, communication competencies, teamwork competencies, creativity competencies, commitment competencies) and the three pillars of sustainability projects (economic, environment, and society) (Adiguzel \& Cakir, 2020; Brook \& Pagnanelli, 2014; Dzhengiz \& Niesten, 2019; Hassan, 2021a; Liikamaa, 2015; Secundo et al., 2020; Wiek et al., 2011). Henceforward, in sustainability projects, team members who do not have these innovation competencies are advised to acquire them through training and daily practice. While team members who already have these innovation competencies can enhance them for a better outcome. Nevertheless, although this research contributes sufficiently to the existing innovation and sustainability literature, some limitations have to be acknowledged. The research findings are based on analyzing earlier research, not an empirical study. At the same time, the model is specific for project team members, not generalized for project stakeholders (e.g., developers, shareholders, contractors, subcontractors, end-users, etc.). Henceforth, future research on this topic is recommended to analyze the results based on an empirical study, and create a model that involves project stakeholders, not only project team members.

\section{Acknowledgments}

Many thanks to the former researchers who have scrutinized on the issues of project team members' innovation competencies and the successful implementation of sustainability projects.

\section{References}

Abu Bakar, A., Abdul Razak, A., Abd Karim, N., Yusof, M., \& Modifa, I. (2011). The role of project managers in improving project performance in construction: An Indonesian experience. International Journal of Academic Research, 3(6), 164-169.

Adiguzel, Z., \& Cakir, F. (2020). Role of diversity management and charismatic leadership on innovation and performance in the globalized era. International Journal of Innovation, 8(3), 489-515. https://doi.org/10.5585/iji.v8i3.17595

Afsar, B., Badir, Y., \& Khan, M. (2015). Person-job fit, person-organization fit and innovative work behavior: The mediating role of innovation trust. The Journal of High Technology Management Research, 26(2), 105-116. https://doi.org/10.1016/j.hitech.2015.09.001

Ahsan, K., Ho, M. \& Khan, S. (2013). Recruiting project managers: A comparative analysis of competencies and recruitment Signals from Job Advertisements. Project Management Journal, 44(5), 36-54. https://doi.org/10.1002/pmj.21366

Aragón-Correa, J., García-Morales, V., \& Cordón-Pozo, E. (2007). Leadership and organizational learning's role on innovation and performance: Lessons from Spain. Industrial 
Marketing Management, 36(3), 349-359. https://doi.org/10.1016/j.indmarman.2005.09.006

Atuahene-Gima, K., \& Wei, Y. (2010). The vital role of problem-solving competence in new product success. Journal of Product Innovation Management, 28(1), 81-98. https://doi.org/10.1111/j.1540-5885.2010.00782.x

Boss, R. (2000). Is the leader really necessary? The longitudinal results of leader absence in team building. Public Administration Quarterly, 23(4), 471-486.

Bossink, B. (2002). The strategic function of quality in the management of innovation. Total Quality Management, 13(2), 195-205. https://doi.org/10.1080/09544120120102432

Brook, J., \& Pagnanelli, F. (2014). Integrating sustainability into innovation project portfolio management - A strategic perspective. Journal of Engineering and Technology Management, 34, 46-62. https://doi.org/10.1016/j.jengtecman.2013.11.004

Bruwer, J., Coetzee, P., \& Meiring, J. (2018). Can internal control activities and managerial conduct influence business sustainability? A South African SMME perspective. Journal of Small Business and Enterprise Development, 25(5), 710-729. https://doi.org/10.1108/JSBED-11-2016-0188

Ciegis, R., Kliucininkas, L., \& Ramanauskiene, J. (2011). Assessment of state and tendencies of sustainable development in Lithuania. Management of Environmental Quality: An International Journal, 22(6), 757-768.

Cunha, M., Rego, A., Oliveira, P., Rosado, P., \& Habib, N. (2014). Product innovation in resource-poor environments: Three research streams. Journal of Product Innovation Management, 31(2), 202-210. https://doi.org/10.1111/jpim.12090

Desidério, P. H. M., Marques, J. C., Cardoso, C. A., Sobr., Bittencourt, I. M., \& Neder, R. (2020). Models of innovation in university-company interaction: Observations in innovation agencies and business organizations. International Journal of Innovation, 8(3), 466-488. https://doi.org/10.5585/iji.v8i3.17392

Dul, J., \& Ceylan, C. (2014). The impact of a creativity-supporting work environment on a firm's product innovation performance. Journal of Product Innovation Management, 31(6), 1254-1267. https://doi.org/10.1111/jpim.12149

Dulaimi, M., Nepal, M., \& Park, M. (2005). A hierarchical structural model of assessing innovation and project performance. Construction Management and Economics, 23(6), 565-577. https://doi.org/10.1080/01446190500126684

Dumitrescu, C., Drăghicescu, L., Olteanu, R., \& Suduc, A. (2014). Key competences for sustainable development - aspects related with sustain project activity. Procedia - Social and Behavioral Sciences, 141, 1101-1105. https://doi.org/10.1016/j.sbspro.2014.05.185

Dzhengiz, T., \& Niesten, E. (2019). Competences for environmental sustainability: A systematic review on the impact of absorptive capacity and capabilities. Journal of Business Ethics, 162(4), 881-906. https://doi.org/10.1007/s10551-019-04360-z 
Dziekoński, K. (2017). Project managers' competencies model for construction industry in Poland. Procedia Engineering, 182, 174-181. https://doi.org/10.1016/j.proeng.2017.03.157

Fukuda-Parr, S., \& Muchhala, B. (2020). The southern origins of sustainable development goals: Ideas, actors, aspirations. World Development, 126, 104706. https://doi.org/10.1016/j.worlddev.2019.104706

Guillén, L. \& Saris, W. (2013). Competencies, personality traits, and organizational rewards of middle managers: A motive-based approach. Human Performance, 26(1), 66-92. https://doi.org/10.1080/08959285.2012.736898

Gumusluoglu, L., \& Ilsev, A. (2009). Transformational leadership, creativity, and organizational innovation. Journal of Business Research, 62(4), 461-473.

Hassan, A. (2021a). The antecedents and challenges of innovation in sustainable development projects: Systematic review. Environmental Management and Sustainable Development, 10(1), 76-91. https://doi.org/10.5296/emsd.v10i1.18329

Hassan, A. (2021b). Towards a conceptual framework to implement corporate sustainability using change management aspects. International Journal Economics, Business and Management Research, 5(1), 58-74.

Hassan, A. (2020). Managerial competencies required to achieve sustainable development projects: A proposed model for managers. Environmental Management and Sustainable Development, 9(3), 68-86. https://doi.org/10.5296/emsd.v9i3.17603

Hossain, M. (2021). Frugal innovation and sustainable business models. Technology in Society, 64, 101508. https://doi.org/10.1016/j.techsoc.2020.101508

Howell, J., Shea, C. \& Higgins, C. (2005). Champions of product innovations: Defining, developing, and validating a measure of champion behavior. Journal of Business Venturing, 20(5), 641-661. https://doi.org/10.1016/j.jbusvent.2004.06.001

Kempner-Moreira, F., Freire, P. S., \& Zilli, J. C. (2020). Corporate governance as an innovative booster: A literature revision. International Journal of Innovation, 8(3), 356-372. https://doi.org/10.5585/iji.v8i3.15037

Lahi, A., \& Elenurm, T. (2015). SME open innovation implicating factors in different innovation phases. International Journal of Management Science \& Technology Information, (16), 29-45.

Liikamaa, K. (2015). Developing a project manager's competencies: A collective view of the most important competencies. Procedia Manufacturing, 3, 681-687. http://dx.doi.org/10.1016/j.promfg.2015.07.305

Maier, D., Maier, A., Aschilean, I., Anastasiu, L., \& Gavris, O (2020). The relationship between innovation and sustainability: A bibliometric review of the literature. Sustainability, 12, 4083. https://doi.org/10.3390/su12104083

Montani, F., Odoardi, C. \& Battistelli, A. (2014). Individual and contextual determinants of 
innovative work behaviour: Proactive goal generation matters. Journal of Occupational \& Organizational Psychology, 87(4), 645-670. https://doi.org/10.1111/joop.12066

Mukhopadhyay, K., Sil, J., \& Banerjea, N. (2011). A competency based management system for sustainable development by innovative organizations: A proposal of method and tool. Vision: The Journal of Business Perspective, 15(2), 153-162. https://doi.org/10.1177/097226291101500206

Müller, R., \& Turner, J. R. (2007). Matching the project manager's leadership style to project type. International Journal of Project Management, 25(1), 21-32. http://dx.doi.org/10.1016/j.ijproman.2006.04.003

Paladino, A. (2007). Investigating the drivers of innovation and new product success: A comparison of strategic orientations. Journal of Product Innovation Management, 24(6), 534-553. https://doi.org/10.1111/j.1540-5885.2007.00270.x

Powl, A., \& Skitmore, M. (2005). Factors hindering the performance of construction project managers. Construction Innovation, 5(1), 41-51. https://doi.org/10.1108/14714170510815168

Remington-Doucette, S., \& Musgrove, S. (2015). Variation in sustainability competency development according to age, gender, and disciplinary affiliation: Implications for teaching practice and overall program structure. International Journal of Sustainability in Higher Education, 16(4), 537-575. https://doi.org/10.1108/IJSHE-01-2013-0005

Ríos-Carmenado, I., Rahoveanu, A. \& Gallegos, A. (2014). Project management competencies for regional development in Romania: Analysis from "working with people" model. Procedia Economics and Finance, 8, 614-621. https://doi.org/10.1016/S2212-5671(14)00136-1

Rojas, E. (2013). Identifying, recruiting, and retaining quality field supervisors and project managers in the electrical construction industry. Journal of Management in Engineering, 29(4), 424-434. https://doi.org/10.1061/(ASCE)ME.1943-5479.0000172

Samson, D., \& Gloet, M. (2014). Innovation capability in Australian manufacturing organisations: an exploratory study. International Journal of Production Research, 52(21), 6448-6466. https://doi.org/10.1080/00207543.2013.869368

Secundo, G., Ndou, V., Vecchio, P., \& De Pascale, G. (2020). Sustainable development, intellectual capital and technology policies: A structured literature review and future research agenda. Technological Forecasting and Social Change, 153, 119917. https://doi.org/10.1016/j.techfore.2020.119917

Shieh, C. (2011). Management innovation, corporation core competence and corporate culture: The impact of relatedness. Applied Economics Letters, 18(12), 1121-1124. https://doi.org/10.1080/13504851.2010.526567

Skulmoski, G., \& Hartman, F. (2010). Information systems project manager soft competencies: A project-phase investigation. Project Management Journal, 41(1), 61-80. https://doi.org/10.1002/pmj.20146 
Sobol, A. (2008). Governance barriers to local sustainable development in Poland. Management of Environmental Quality: An International Journal, 19(2), 194-203. https://doi.org/10.1108/14777830810856573

Takey, S., \& Carvalho, M. (2015). Competency mapping in project management: An action research study in an engineering company. International Journal of Project Management, 33(4), 784-796. https://doi.org/10.1016/j.ijproman.2014.10.013

Vila, L., Pérez, P. \& Coll-Serrano, V. (2014). Innovation at the workplace: Do professional competencies matter? Journal of Business Research, 67(5), 752-757. https://doi.org/10.1016/j.jbusres.2013.11.039

Wei, Y., O'Neill, H., Lee, R., \& Zhou, N. (2013). The impact of innovative culture on individual employees: The moderating role of market information sharing. Journal of Product Innovation Management, 30(5), 1027-1041. https://doi.org/10.1111/j.1540-5885.2012.01000.x

Wiek, A., Withycombe, L., \& Redman, C. (2011). Key competencies in sustainability: A reference framework for academic program development. Sustainability Science, 6(2), 203-218. https://doi.org/10.1007/s11625-011-0132-6

\section{Copyrights}

Copyright for this article is retained by the author(s), with first publication rights granted to the journal.

This is an open-access article distributed under the terms and conditions of the Creative Commons Attribution license (http://creativecommons.org/licenses/by/4.0/) 